\title{
Determination of Ultralow Level 135Cs and 135Cs/137Cs Ratio in Environmental Samples by Chemical Separation and Triple Quadrupole ICP-MS
}

Zhu, Liuchao; Hou, Xiaolin; Qiao, Jixin

Published in:

Analytical Chemistry

Link to article, DOI:

10.1021/acs.analchem.0c01153

Publication date:

2020

Document Version

Publisher's PDF, also known as Version of record

Link back to DTU Orbit

Citation (APA):

Zhu, L., Hou, X., \& Qiao, J. (2020). Determination of Ultralow Level 135Cs and 135Cs/137Cs Ratio in Environmental Samples by Chemical Separation and Triple Quadrupole ICP-MS. Analytical Chemistry, 92(11), 7884-7892. https://doi.org/10.1021/acs.analchem.0c01153

\section{General rights}

Copyright and moral rights for the publications made accessible in the public portal are retained by the authors and/or other copyright owners and it is a condition of accessing publications that users recognise and abide by the legal requirements associated with these rights.

- Users may download and print one copy of any publication from the public portal for the purpose of private study or research.

- You may not further distribute the material or use it for any profit-making activity or commercial gain

- You may freely distribute the URL identifying the publication in the public portal 


\title{
Determination of Ultralow Level ${ }^{135} \mathrm{Cs}$ and ${ }^{135} \mathrm{Cs} /{ }^{137} \mathrm{Cs}$ Ratio in Environmental Samples by Chemical Separation and Triple Quadrupole ICP-MS
}

\author{
Liuchao Zhu, Xiaolin Hou,* and Jixin Qiao
}

Cite This: https://dx.doi.org/10.1021/acs.analchem.0c01153

Read Online

回 Article Recommendations

S1 Supporting Information

ABSTRACT: An analytical method was developed for the determination of ultralow level ${ }^{135} \mathrm{Cs}$ in environmental samples by chromatographic separation of cesium with AMP-PAN and AG50W-X8 columns and sensitive measurement of cesium isotopes with triple quadrupole inductively coupled plasma mass spectrometry (ICP-MS/MS). Cesium was simply released by acid leaching using aqua regia from environmental solid samples and preconcentrated on AMP-PAN column. The cesium adsorbed on the column was effectively eluted with $\mathrm{NH}_{4} \mathrm{Cl}$ solution without dissolving the AMP. The excessive amount of $\mathrm{NH}_{4} \mathrm{Cl}$ in the eluate was removed by sublimation in the presence of small amount of

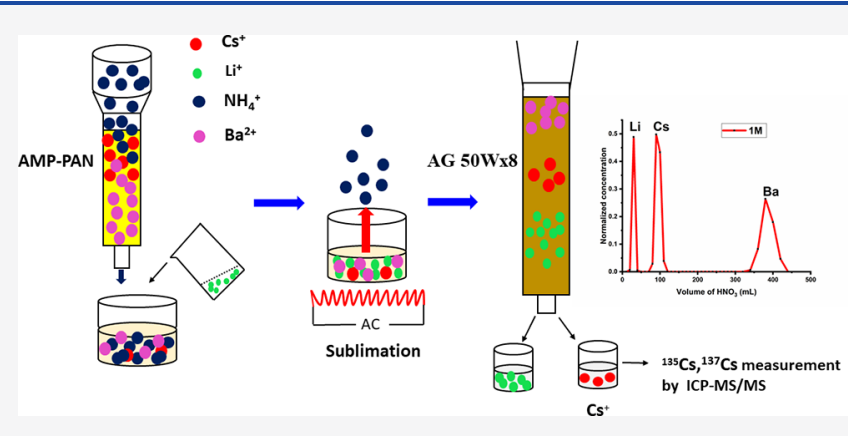
$\mathrm{LiCl}$. The remaining barium and other interfering elements such as $\mathrm{Mo}, \mathrm{Sn}, \mathrm{Sb}$, and $\mathrm{Li}$ were efficiently removed using cation exchange chromatography (AG50W-X8). The decontamination factors of this procedure are above $4 \times 10^{7}$ for barium and $4 \times 10^{5}$ for molybdenum; the chemical yields of cesium are more than $85 \%$ for samples of less than $10 \mathrm{~g}$. This method enables to separate cesium from large size of samples for the determination of ultralow level ${ }^{135} \mathrm{Cs}$, avoiding the problem of removal of a huge amount of Mo in the dissolved AMP. Intrinsic ${ }^{137} \mathrm{Cs}$ in the environmental samples measured by gamma spectrometry before and after separation was used as internal isotope dilution standard for quantitative determination of ${ }^{135} \mathrm{Cs}$ without complete release and recover of radiocesium. The interference of barium $\left({ }^{135} \mathrm{Ba}\right.$ and $\left.{ }^{137} \mathrm{Ba}\right)$ to the ICP-MS measurement of ${ }^{135} \mathrm{Cs}$ and ${ }^{137} \mathrm{Cs}$ was further suppressed to $8 \times 10^{-5}$ by using $\mathrm{N}_{2} \mathrm{O}$ as the reaction gas in ICP-MS/MS at a flow rate of $0.7 \mathrm{~mL} / \mathrm{min}$, so a total suppression of $2 \times$ $10^{-12}$ for Ba was achieved, making the isobaric interference of $\mathrm{Ba}$ isotopes to the measurement of ${ }^{135} \mathrm{Cs}$ and ${ }^{137} \mathrm{Cs}$ in environmental samples negligible. A detection limit of $9.1 \times 10^{-17} \mathrm{~g} / \mathrm{g}$ for ${ }^{135} \mathrm{Cs}$ and ${ }^{137} \mathrm{Cs}$ was achieved for $60 \mathrm{~g}$ samples. The developed method was validated by analysis of standard reference materials (IAEA-375, IAEA-330, and IAEA-385) and successfully applied for the determination of ${ }^{135} \mathrm{Cs}$ concentrations and ${ }^{135} \mathrm{Cs} /{ }^{137} \mathrm{Cs}$ ratios in soil samples collected from Denmark, Sweden, and Ukraine. The ${ }^{135} \mathrm{Cs} /{ }^{137} \mathrm{Cs}$ isotopic ratios in Danish soil (2.08-2.68) were significantly higher than that from Sweden and Ukraine (0.65-0.71), indicating different sources of radiocesium. This work demonstrated the application of ${ }^{135} \mathrm{Cs} /{ }^{137} \mathrm{Cs}$ as a unique fingerprint for discriminating the sources of radioactive contamination and estimating their contribution to the total inventory, which will be useful for nuclear forensics and environmental tracer studies.

$\mathrm{R}_{\mathrm{s}}$ adioisotopes of cesium are important in environmental protection due to their high production and volatile feature of cesium; among them, ${ }^{137} \mathrm{Cs}$ and ${ }^{134} \mathrm{Cs}$ are the major concern. ${ }^{135} \mathrm{Cs}$ is one of important radionuclides in the waste repository due to its long half-life $\left(2.3 \times 10^{6}\right.$ years $)$ and relatively large inventory. These radioisotopes of cesium are mainly produced by fission of nuclear fuel with some neutron activation production of ${ }^{134} \mathrm{Cs}$, and released to the environment mainly by atmospheric nuclear weapons tests, nuclear accidents, spent nuclear fuel reprocessing plants, and nuclear power and research reactors. ${ }^{1}$ Based on the source specific ${ }^{134} \mathrm{Cs} /{ }^{137} \mathrm{Cs}$ ratios, they have been used as tracers for identification of sources of radioactive substances, ${ }^{2,3}$ estimation of sedimentation rate, and circulation of water mass in the ocean. ${ }^{4,5}$ However, due to the short half-life of ${ }^{134} \mathrm{Cs}(2.1$ years), the ${ }^{134} \mathrm{Cs} /{ }^{137} \mathrm{Cs}$ ratio can only be used for a limited time ( $<10$ years). The Fukushima derived ${ }^{134} \mathrm{Cs}$ in the environment has already been difficult to measure in the present environmental samples.

In the production of ${ }^{135} \mathrm{Cs}$ by fission of nuclear fuel, besides direct fission production of ${ }^{135} \mathrm{Cs}$, most ${ }^{135} \mathrm{Cs}$ is produced by the decay of other short-lived fission products of isobars

Received: March 16, 2020

Accepted: May 5, 2020

Published: May 5, 2020 
$\left({ }^{135} \mathrm{Te},{ }^{135} \mathrm{I}\right.$ and $\left.{ }^{135} \mathrm{Xe}\right)$. Due to an extremely large neutron capture cross section $\left(2 \times 10^{6} \mathrm{~b}\right)$, part of the formed ${ }^{135} \mathrm{Xe}$ is converted to ${ }^{136} \mathrm{Xe}$ instead of decaying to ${ }^{135} \mathrm{Cs}$, causing the accumulated fission yield of ${ }^{135} \mathrm{Cs}$ to vary with neutron flux and irradiation time. While, the fission yield of ${ }^{137} \mathrm{Cs}$ does not change because of no such neutron poison in the fission chain production of ${ }^{137} \mathrm{Cs}$. The ${ }^{135} \mathrm{Cs} /{ }^{137} \mathrm{Cs}$ ratio therefore shows a source dependent value and is related to the neutron flux and irradiation time of the nuclear fuel $\left({ }^{235} \mathrm{U}\right.$ or $\left.{ }^{239} \mathrm{Pu}\right),{ }^{6}$ which makes it a fingerprint for source identification or indicator of nuclear power plant operation. ${ }^{7}$ The ${ }^{135} \mathrm{Cs} /{ }^{137} \mathrm{Cs}$ atomic ratio at the time of explosion of nuclear weapons was estimated to be 1.0 , and the global fallout ${ }^{135} \mathrm{Cs} /{ }^{137} \mathrm{Cs}$ atomic ratio was measured to be 3.7 until $2020 .{ }^{8}$ Much lower ${ }^{135} \mathrm{Cs} /{ }^{137} \mathrm{Cs}$ ratios of 0.28-0.32 for the Chernobyl derived radiocesium (decay corrected to April 1986) $)^{9}$ and $0.33-0.38$ for the Fukushima derived radiocesium (decay corrected to March 2011) ${ }^{10}$ were reported, while various ratios of ${ }^{135} \mathrm{Cs} /{ }^{137} \mathrm{Cs}$ of $0.4-1.6$ in the discharges from reprocessing plants and influent from nuclear reactors were reported, ${ }^{11}$ reflecting the influence of neutron flux and irradiation time, as well as the time interval between production and analysis. This shows the potential to replace the short-lived ${ }^{134} \mathrm{Cs}$ with ${ }^{135} \mathrm{Cs}$ in tracer applications. ${ }^{12-16}$

As a low-energy beta emitter, the measurement of ${ }^{135} \mathrm{Cs}$ by radiometric method is usually hindered by the coexistence of high-energy beta emitter ${ }^{137} \mathrm{Cs}$, which is often several orders of magnitude higher radioactivity compared to that for ${ }^{135} \mathrm{Cs}$. Mass spectrometry is therefore a practical technique for ${ }^{135} \mathrm{Cs}$ measurement in the environmental samples. Among them, resonance ionization mass spectrometry (RIMS), ${ }^{17}$ thermal ionization mass spectrometry (TIMS), ${ }^{18-20}$ sector field inductively coupled plasma-mass spectrometry (SF-ICPMS), ${ }^{21,22}$ electric thermal vaporization ICP-MS (ETV-ICP$\mathrm{MS}),{ }^{23}$ and triple quadrupole inductively coupled plasma mass spectrometry (ICP-MS/MS) ${ }^{12-14}$ have been used for this purpose. ICP-MS/MS is becoming the most attractive mass spectrometric technique for the measurement of ${ }^{135} \mathrm{Cs}$ due to its highest popularity, high abundance sensitivity, and excellent removal of barium interference by reaction cell technique.

Due to the low concentration of ${ }^{135} \mathrm{Cs}$ in ordinary environmental samples $(<1 \mathrm{mBq} / \mathrm{kg})$, cesium needs to be preconcentrated and separated from the sample matrix and interferences before measurement. It has been widely reported that cesium is strongly bound in minerals in the soil and sediment, ${ }^{1}$ and it is therefore important to effectively release the binding radiocesium from sample matrix to the solution before chemical separation. The elimination of isobaric interference is the most critical issue for the accurate measurement of ${ }^{135} \mathrm{Cs}$ and ${ }^{137} \mathrm{Cs}$ by ICP-MS/MS, because the mass concentrations of stable isobars $\left({ }^{135} \mathrm{Ba}\right.$ and $\left.{ }^{137} \mathrm{Ba}\right)$ are more than 8 orders of magnitude higher than ${ }^{135} \mathrm{Cs}$ and ${ }^{137} \mathrm{Cs}$ in the environmental samples. The interference of polyatomic ions formed by $\mathrm{Mo}, \mathrm{Sn}$, and $\mathrm{Sb}$ with isotopes of light elements (e.g., O, S, Ar, etc.) is another critical issue and has to be resolved. Due to the specific adsorption of Cs, AMP powder and AMP-PAN resin have been used to isolate Cs from the sample matrix, and the AMP matrix with adsorbed Cs was usually dissolved with ammonia for further purification of cesium. A combined anion and cation exchange chromatographic (AG MP-1 M and AG 50W-X8) separation procedure has been reported, ${ }^{13,14}$ in which $\mathrm{MoO}_{4}{ }^{2-}$ in the sample solution was removed by anion exchange column, and the Cs remained in the effluent was purified using a cation exchange column. This method has been successfully applied for analysis of Fukushima accident derived environmental samples. ${ }^{13,14}$ However, it might be not suitable for analysis of large size of environmental background samples (e.g., $>100 \mathrm{~g}$ soil or sediment and large volume of seawater) with ultralow level ${ }^{135}$ Cs. In this case, a large amount of AMP powder or AMPPAN resin needs to be used to preconcentrate cesium, consequently a massive amount of $\mathrm{Mo}$ and $\mathrm{Ba}$ is introduced to the sample solution by complete dissolution of AMP using ammonia, which will make the following purification of Cs from Mo and $\mathrm{Ba}$ very challenging.

This work aims to develop a method for accurate determination of ultralow level ${ }^{135} \mathrm{Cs}$ in large size environmental solid samples. The work focuses on effective release of cesium from environmental solid samples, selective separation of cesium from sample matrix using a AMP-PAN column without introducing Mo into sample solution, complete elimination of barium isobaric interference, and sensitive measurement of ${ }^{135} \mathrm{Cs}$ and ${ }^{137} \mathrm{Cs}$ using ICP-MS/MS.

\section{EXPERIMENTAL SECTION}

Instrumentation. A triple-quadrupole ICP-MS instrument (Agilent 8800, U.S.A.) was employed for the measurement of ${ }^{135} \mathrm{Cs}$ and ${ }^{137} \mathrm{Cs}$ in this work, which was equipped with an octopole dynamic reaction cell (DRC) between two quadrupole mass filters. The first quadrupole (Q1) selects the target ions with certain $m / z$ values (e.g., $m / z=135$ and 137 ) and introduces it into the DRC. The collision/reaction gas injected to the DRC reacts with the entered ions to remove the interfering ions by forming new ions. The analyte ions (original or newly formed) are selected in the second quadrupole (Q2) and measured in the following detector. $\mathrm{N}_{2} \mathrm{O}$ gas $(99.999 \%$ purity) was injected to the DRC as collision/reaction gas. Apex-Q sample introduction system (Elemental Scientific Instruments, U.S.A.) was used to improve the sensitivity of cesium isotopes.

Reagents and Samples. All reagents used in this work were of analytical reagent grade. Ultrapure water (18.2 M $\Omega$ $\mathrm{cm}$, Sartorius water purification system, arium pro VF) and distilled $\mathrm{HNO}_{3}$ (by Savillex DST-1000 system, U.S.A.) were used for preparation of cesium solution from AG 50W-X8 column for ICP-MS/MS measurement. AMP-PAN (100-600 $\mu \mathrm{m}$, Triskem International) resin and strong acidic cation exchange resin AG 50W-X8 (100-200 mesh, $\mathrm{H}^{+}$form, analytical grade, Bio-Rad laboratories) were used for separation and purification of cesium.

Reference materials IAEA-375 (soil, collected from Novozybkov, Bryansk, Russia in 1990), IAEA-385 (Irish sea sediment, collected in 1995), and IAEA-330 (spinach, collected from Polesskoe, Kiev, Ukraine in 1990) were purchased from the International Atomic Energy Agency (IAEA). Two Danish soil samples were analyzed in this study, one (Soil-1) was collected from 0 to $5 \mathrm{~cm}$ using a stainless steel cylinder in Roskilde, and another one (Soil-2) is a mixed surface soil $(0-5 \mathrm{~cm})$, which was collected from 8 different sites (Tylstrup, Borris, Askov, St. Jyndevad, Tystofte, Tornbygård) in Denmark. One soil from Gavle, Sweden and three soils from Feofaniya, Ukraine were collected from 0 to 5 $\mathrm{cm}$ depth in 1992. The sampling sites are shown in Figure S1.

Release of Cesium from Solid Samples. Soil or sediment samples were first oven-dried at $80^{\circ} \mathrm{C}$ and then ashed in a muffle oven at $450{ }^{\circ} \mathrm{C}$ for $8 \mathrm{~h}$ to decompose the 
organic substances. A total of $1-60 \mathrm{~g}$ of soil samples were used in this work depending on the measured ${ }^{137} \mathrm{Cs}$ level. Two methods were applied to release cesium from soil/sediment samples, one was acid leaching using aqua regia and the other one was fusion using $\mathrm{LiBO}_{2}$. For acid leaching, aqua regia was added to the ashed soil or sediment with a ratio of 8 for acid/ sample $(\mathrm{mL} / \mathrm{g})$. A small volume of acid $(\mathrm{HCl})$ was slowly added to the sample to dissolve carbonate to avoid a sudden release of a large amount of $\mathrm{CO}_{2}$, which could cause a spillover of the sample out of the beaker. The sample with acid solution in a beaker was covered with a watch glass and heated at 180 ${ }^{\circ} \mathrm{C}$ for $2 \mathrm{~h}$ on a hot plate. The leachate was separated by filtration through a glass fiber filter, the residue was washed with diluted $\mathrm{HCl}$ and the washing solution was combined with leachate. For fusion method, $\mathrm{LiBO}_{2}$ was mixed with the ashed soil in a graphite crucible with a mass ratio of $1: 2$ for sample/ $\mathrm{LiBO}_{2}$. The sample with $\mathrm{LiBO}_{2}$ was fused at $950{ }^{\circ} \mathrm{C}$ for 20 min. The obtained molten button of sample was dissolved with aqua regia, and the solution was used for separation of cesium. The residue was dried and measured for the remaining ${ }^{137} \mathrm{Cs}$ to monitor the recovery in this step. The leachate was evaporated to near-dryness and dissolved in $1.0 \mathrm{M} \mathrm{HNO}_{3}$.

Separation of Cesium Using AMP-PAN Column. Cesium was separated and purified from the sample matrix and interferences using AMP-PAN column followed by a cation exchange (AG 50W-X8) chromatography. The prepared sample solution was loaded into an AMP-PAN column (1.0 $\mathrm{mL}$ resin packed in a $2 \mathrm{~mL}$ column, $\phi 7 \mathrm{~mm} \times 5 \mathrm{~cm}$ ), which has been preconditioned with $40 \mathrm{~mL}$ of $4 \mathrm{M} \mathrm{NH}_{4} \mathrm{NO}_{3}, 20 \mathrm{~mL}$ of ultrapure $\mathrm{H}_{2} \mathrm{O}$, and $10 \mathrm{~mL}$ of $1 \mathrm{M} \mathrm{HNO}_{3}$. The column was rinsed with $30 \mathrm{~mL}$ of $1 \mathrm{M} \mathrm{HNO}_{3}$ and $20 \mathrm{~mL}$ of deionized $\mathrm{H}_{2} \mathrm{O}$ to remove matrix elements. Cesium adsorbed on the column was eluted with selected ammonium salt (e.g., $\mathrm{NH}_{4} \mathrm{Cl}$, $\mathrm{NH}_{4} \mathrm{NO}_{3}$, and $\left.\left(\mathrm{NH}_{4}\right)_{2} \mathrm{SO}_{4}\right)$.

Removal of $\mathrm{NH}_{4} \mathrm{Cl}$ Salt from the Eluate of Cesium. Before further purification of cesium (eluted from AMP-PAN column) using cation exchange chromatography, $\mathrm{NH}_{4} \mathrm{Cl}$ needs to be removed because of the competitive adsorption of $\mathrm{NH}_{4}^{+}$ with $\mathrm{Cs}^{+}$on the cation exchange resin. The $\mathrm{NH}_{4} \mathrm{Cl}$ eluate with cesium was heated to dryness on a hot plate at $180{ }^{\circ} \mathrm{C}$ after adding $\mathrm{LiCl}$ (or other protective reagents). The residue in the beaker was then heated at different temperature (e.g., 350, 400, and $450{ }^{\circ} \mathrm{C}$ ) for about $1-2 \mathrm{~h}$ in a muffle oven to remove $\mathrm{NH}_{4} \mathrm{Cl}$. After cooling to room temperature, the remaining residue was dissolved with $10 \mathrm{~mL}$ of $1.5 \mathrm{M} \mathrm{NH}_{3} \cdot \mathrm{H}_{2} \mathrm{O}$. For method development, a small fraction of the solution $(0.1 \mathrm{ml})$ was taken for the measurement of Cs content using ICP-MS to monitor the recovery of cesium in this step.

Purification of Cesium from Li, Ba, and Mo. The obtained sample solution from the last step was loaded onto a cation exchange column (10 mL of AG 50W-X8, $\phi 1.0 \mathrm{~cm} \times 20$ $\mathrm{cm}, \mathrm{H}^{+}$form), which was preconditioned with $50 \mathrm{~mL}$ of $5.0 \mathrm{M}$ $\mathrm{HNO}_{3}, 20 \mathrm{~mL}$ of deionized $\mathrm{H}_{2} \mathrm{O}$, and $20 \mathrm{~mL}$ of $1.5 \mathrm{M} \mathrm{NH}_{3}$. $\mathrm{H}_{2} \mathrm{O}$. The column was rinsed with $50 \mathrm{~mL}$ of $1.5 \mathrm{M} \mathrm{NH}_{3} \cdot \mathrm{H}_{2} \mathrm{O}$ and $20 \mathrm{~mL}$ of deionized $\mathrm{H}_{2} \mathrm{O}$ (and $70 \mathrm{~mL}$ of $1 \mathrm{M} \mathrm{HNO}_{3}$ for optimized procedure). Cesium remaining in the column was eluted with different concentrations of $\mathrm{HNO}_{3}$ (e.g., 0.5, 1.0, 1.5 , and $2.0 \mathrm{M}$ ). For method development, each $10 \mathrm{~mL}$ of eluate was collected and measured for $\mathrm{Li}, \mathrm{Cs}$, and $\mathrm{Ba}$ using ICP-MS to obtain an elution curve. For analysis of samples, the collected eluate of cesium (e.g., $70 \mathrm{~mL}$ of $1 \mathrm{M} \mathrm{HNO}_{3}$ ) was evaporated to dryness and redissolved with $2 \mathrm{~mL}$ of $0.30 \mathrm{M}$ $\mathrm{HNO}_{3}$ for measurement of ${ }^{135} \mathrm{Cs} /{ }^{137} \mathrm{Cs}$ ratio using ICP-MS/
MS. The schematic diagram of the optimized analytical procedure is shown in Figure S2.

Measurement of ${ }^{137}$ Cs Using Gamma Spectrometry. Radioactivity of ${ }^{137} \mathrm{Cs}$ in all samples was measured using an $\mathrm{HPGe}$ gamma spectrometer (with a relative counting efficiency of $35 \%$ and a resolution of $1.85 \mathrm{keV}$ for $1332 \mathrm{keV}$ gamma peak of ${ }^{60} \mathrm{Co}$ ) by counting its $661.6 \mathrm{keV} \gamma$ rays. The dried samples were sealed into a plastic container and put on the top of the detector (nearest distance). Gennie 2000 software (Canberra) was used to acquire gamma spectra and perform spectra analysis. The gamma spectrometry was calibrated for counting efficiency using a mixed gamma standard; the measurement results of ${ }^{137} \mathrm{Cs}$ were corrected for counting geometry, selfabsorption (density and sample components), and sum coincidence.

Measurement of Cesium Isotopes $\left({ }^{135} \mathrm{Cs}\right.$ and $\left.{ }^{137} \mathrm{Cs}\right)$ with ICP-MS/MS. Cesium isotopes $\left({ }^{135} \mathrm{Cs}\right.$ and $\left.{ }^{137} \mathrm{Cs}\right)$ in the prepared solution were measured using ICP-MS/MS. The instrument was tuned using stable ${ }^{133} \mathrm{Cs}(1.0 \mathrm{ng} / \mathrm{mL})$ prepared using cesium standard solution (CPI international, Amsterdam, Netherlands). The blanks, standards, and samples were prepared in $0.30 \mathrm{M} \mathrm{HNO}_{3}$ for measurement. The sample solution was introduced using MicroMist nebulizer with a peristaltic pump at $0.1 \mathrm{~mL} / \mathrm{min}$ for ${ }^{133} \mathrm{Cs}$ measurement and optimization of the instrument setup. Pt skimmer cone, s-lens, and hot plasma were used in the measurement of cesium isotopes. $\mathrm{N}_{2} \mathrm{O}$ (99.999\% purities) was injected to the DRC as reaction gas in the measurement of ${ }^{135} \mathrm{Cs}$ and ${ }^{137} \mathrm{Cs}$. For measurement of ${ }^{135} \mathrm{Cs}$ and ${ }^{137} \mathrm{Cs}$ in low-level environmental samples, an Apex-Q sample introduction system was employed to improve nebulization efficiency, measurement sensitivity of cesium isotopes and analytical precision. For measurement of ${ }^{135} \mathrm{Cs}$, both Q1 and Q2 were set to $m / z=135$, and for ${ }^{137} \mathrm{Cs}$, they were set to 137 .

\section{RESULTS AND DISCUSSION}

Extraction of Cesium from Environmental Solid Samples. Both acid leaching using aqua regia and complete decomposition using $\mathrm{LiBO}_{2}$ fusion followed by acid dissolution were investigated for releasing radiocesium $\left({ }^{135} \mathrm{Cs}\right.$ and $\left.{ }^{137} \mathrm{Cs}\right)$ from the soil/sediment to solution. Since both ${ }^{135} \mathrm{Cs}$ and ${ }^{137} \mathrm{Cs}$ in the environment were originated from human nuclear activities, and their chemical properties and environmental behaviors are similar, ${ }^{137} \mathrm{Cs}$ was therefore measured in the samples before and after decomposition using gamma spectrometry and the efficiency of the decomposition methods was evaluated. The results (Table S1) show that a high recovery of more than $93 \%$ for ${ }^{137} \mathrm{Cs}$ was observed using $\mathrm{LiBO}_{2}$ fusion. This should be attributed to the complete decomposition of the sample indicated by the entire melt of the sample with flux at high temperature. A small loss of ${ }^{137} \mathrm{Cs}$ in this method might be attributed to the following dissolution of the molten button. It is interesting that acid leaching using aqua regia also showed a high leaching efficiency of ${ }^{137} \mathrm{Cs}$ from soil/sediment, for less than $10 \mathrm{~g}$ of samples, more than $85 \%$ of ${ }^{137} \mathrm{Cs}$ was leached, and even for a sample of up to $60 \mathrm{~g}$, the ${ }^{137} \mathrm{Cs}$ recovery was higher than $60 \%$. This indicates that acid leaching is sufficiently good for releasing ${ }^{135} \mathrm{Cs}$ and ${ }^{137} \mathrm{Cs}$ from soil/sediment. Since the acid leaching is simple, easy operation, less time-consuming, and more suitable for treatment of a large size sample compared with fusion method, acid leaching using aqua regia with a sample/acid ratio of $1: 8$ at $180{ }^{\circ} \mathrm{C}$ for $2 \mathrm{~h}$ is 
recommended and used in this work. The content of ${ }^{137} \mathrm{Cs}$ in the original samples and the separated cesium samples were measured using gamma spectrometry to calculate the recovery of ${ }^{135} \mathrm{Cs}$ in the chemical separation procedure. ${ }^{135} \mathrm{Cs} /{ }^{137} \mathrm{Cs}$ atomic ratios in the final prepared samples were measured using ICP-MS/MS, which was used in combination with the measured ${ }^{137} \mathrm{Cs}$ concentrations in the original samples for calculation of ${ }^{135} \mathrm{Cs}$ concentrations in the samples, i.e., ${ }^{137} \mathrm{Cs}$ was used as an internal isotope dilution standard, as well as a chemical yield tracer. Meanwhile the incomplete release and recover of ${ }^{135} \mathrm{Cs}$ in the sample preparation does not influence the final analytical results of ${ }^{135} \mathrm{Cs}$ concentration. ${ }^{12}$ It has been widely reported that ${ }^{137} \mathrm{Cs}$ deposited in soil from human nuclear activities was firmly bound to soil grains and mainly in the clay minerals and micas component by occupying/ replacing the site of potassium in the crystal of clay minerals. ${ }^{23-26}$ The fractionation analysis of soil and sediment samples has shown that only a small percentage of ${ }^{137} \mathrm{Cs}$ presents as exchangeable, or associated with carbonate, organic substances or oxides, but mainly associated with minerals, ${ }^{27}$ and aqua regia could leach $70-95 \%$ of ${ }^{137} \mathrm{Cs}$ from the soil and sediment. The leaching efficiency of ${ }^{137} \mathrm{Cs}$ is also highly related to the type and properties of the sample. For soil/sediment sample, ashing at relatively low temperature $\left(450{ }^{\circ} \mathrm{C}\right)$ is necessary for decomposition of organic substances and avoiding loss of cesium at high temperature due to its volatile property.

Preconcentration of Cesium from Sample Solution by AMP-PAN Column. The acid leachate of the sample contains high level of matrix elements (cations), a preconcentration of cesium from the sample matrix is needed before further purification. Due to the selective adsorption of cesium, AMP powder or AMP-PAN column were widely applied for preconcentration of cesium from seawater or sample solution. ${ }^{1}$ Our experiment showed that more than $97 \%$ cesium in the acidic solution (e.g., $1 \mathrm{M} \mathrm{HNO}_{3}$ ) can be adsorbed on AMP powder or AMP-PAN resin. For the determination of ${ }^{135} \mathrm{Cs}$, the adsorbed cesium on the AMP or AMP-PAN resin needs to be eluted for further purification and measurement of ${ }^{135} \mathrm{Cs}$ using ICP-MS/MS. Ammonia has been used to remove cesium from AMP powder. ${ }^{14}$ In this case, all AMP was dissolved. Consequently, all interference elements (e.g., Ba, Mo, Sn, Sb, etc.) also entered into the sample solution, which will influence removal of these interferences. Meanwhile, large amounts of molybdate, phosphate, and potassium were also dissolved into the solution, which significantly influence the further purification of cesium from interferences. The highly selective adsorption of $\mathrm{Cs}^{+}$on AMP-PAN is based on the replacement of $\mathrm{NH}_{4}^{+}$in the AMP by $\mathrm{Cs}^{+}$. Therefore, a high concentration of $\mathrm{NH}_{4}^{+}$solution might be possible to replace and elute $\mathrm{Cs}^{+}$ adsorbed on the AMP-PAN without dissolving the AMP component. The elution characteristics of $\mathrm{Cs}^{+}$from the AMPPAN column with different ammonium salts were investigated. The results show that $\mathrm{NH}_{4} \mathrm{HCO}_{3},\left(\mathrm{NH}_{4}\right)_{2} \mathrm{CO}_{3}, \mathrm{NH}_{4} \mathrm{~F}$, $\mathrm{NH}_{4} \mathrm{C}_{2} \mathrm{O}_{4}, \mathrm{NH}_{4} \mathrm{Ac}$, and $\mathrm{NH}_{4}$ Citr solution can directly dissolve AMP component, similar as ammonia solution, therefore these reagents could not be used for this purpose. Ammonium thiocyanate solution can react with AMP and reduce it to phosphorus molybdenum blue, as indicated by the color change of the AMP-PAN resin from yellow to blue. $\mathrm{NH}_{4} \mathrm{Cl}$, $\mathrm{NH}_{4} \mathrm{NO}_{3}$, and $\left(\mathrm{NH}_{4}\right)_{2} \mathrm{SO}_{4}$ solutions do not dissolve AMP but could elute $\mathrm{Cs}^{+}$from the AMP-PAN resin. In the eluate of these reagents, the high concentration of $\mathrm{NH}_{4}^{+}$will strongly influence the further separation of $\mathrm{Cs}^{+}$using cation exchange chromatography because of its competitive adsorption with $\mathrm{Cs}^{+}$on the resin and has to be removed before separation. Considering the easy removal of $\mathrm{NH}_{4} \mathrm{Cl}$ by the heating method based on its sublimation at low temperatures $\left(338^{\circ} \mathrm{C}\right)$, the risk for dangerous explosion of $\mathrm{NH}_{4} \mathrm{NO}_{3}$ during heating, and difficulties in removal of sulfate, $\mathrm{NH}_{4} \mathrm{Cl}$ was selected to elute $\mathrm{Cs}^{+}$from the AMP-PAN resin.

The elution profiles of $\mathrm{Cs}^{+}$from AMP-PAN column (1.0 $\mathrm{mL}$ ) with different concentrations of $\mathrm{NH}_{4} \mathrm{Cl}$ solution (Figure 1) show that cesium can be efficiently eluted with high

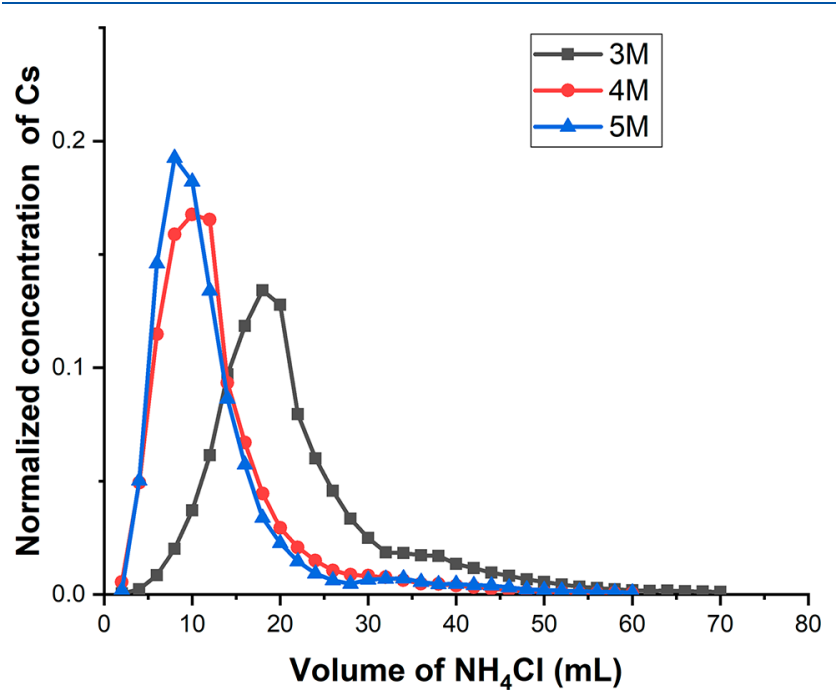

Figure 1. Elution profiles of $\mathrm{Cs}$ with different concentrations of $\mathrm{NH}_{4} \mathrm{Cl}$ solution from $1 \mathrm{~mL}$ of AMP-PAN column.

concentration of $\mathrm{NH}_{4} \mathrm{Cl}$, and a recovery of $>95 \%$ for cesium was obtained using $40 \mathrm{~mL}$ of $4 \mathrm{M}$ or $5 \mathrm{M} \mathrm{NH}_{4} \mathrm{Cl}$. While, a large volume and long tailing were observed when eluted with $3 \mathrm{M}$ or lower concentrations of $\mathrm{NH}_{4} \mathrm{Cl}$. In considering the amount of $\mathrm{NH}_{4} \mathrm{Cl}$ in the eluate, $40 \mathrm{~mL}$ of $4.0 \mathrm{M}$ of $\mathrm{NH}_{4} \mathrm{Cl}$ was applied to elute cesium from $1 \mathrm{~mL}$ of AMP-PAN column.

In addition, the AMP-PAN column can efficiently remove $\mathrm{Ba}, \mathrm{Sb}$, and $\mathrm{Sn}$ by factors of 7300,20 , and 1400, respectively, which are much better than that using AMP powder. ${ }^{14}$ This is very critical to achieve a better separation of $\mathrm{Cs}$ from $\mathrm{Ba}$ and other interfering elements in a large size soil or sediment samples (e.g., $60 \mathrm{~g}$ ) for ultralow-level ${ }^{135} \mathrm{Cs}$ measurement.

Removal of Ammonium from Cs Eluate. Cation exchange chromatography demonstrated an effective technique for purifying cesium from $\mathrm{Ba}$ and other interfering elements. However, due to the competitive adsorption, almost no adsorption of $\mathrm{Cs}^{+}$on the AG 50W-X8 column $(10 \mathrm{~mL})$ was observed when directly loading the cesium eluate in $4 \mathrm{M}$ $\mathrm{NH}_{4} \mathrm{Cl}$ medium. The massive $\mathrm{NH}_{4}{ }^{+}$ions in the eluate have to be removed prior to the purification of cesium by cation exchange chromatography. However, due to the similar chemical properties of $\mathrm{Cs}^{+}$and $\mathrm{NH}_{4}^{+}$, it is difficult to remove $\mathrm{NH}_{4}^{+}$without loss of $\mathrm{Cs}^{+}$. Based on the low sublimation temperature of $\mathrm{NH}_{4} \mathrm{Cl}\left(338{ }^{\circ} \mathrm{C}\right)$ but not $\mathrm{CsCl}$, a simple heating method was developed to remove $\mathrm{NH}_{4} \mathrm{Cl}$ by sublimation. The eluate was first evaporated to dryness on a hot plate; the residue was then heated at $350-450{ }^{\circ} \mathrm{C}$ to remove $\mathrm{NH}_{4} \mathrm{Cl}$. The results show that almost all $\mathrm{NH}_{4} \mathrm{Cl}$ was sublimated at a temperature of above $350{ }^{\circ} \mathrm{C}$ for more than 2 h. However, it was observed that most of cesium (>60\%) was 
also lost when $\mathrm{NH}_{4} \mathrm{Cl}$ was sublimated, even heated at only 350 ${ }^{\circ} \mathrm{C}$ (Table 1).

Table 1. Recoveries of Cesium during the Sublimation of $\mathrm{NH}_{4} \mathrm{Cl}$ Eluate at Different Temperatures and Different Protective Reagents

\begin{tabular}{|c|c|c|c|c|}
\hline $\begin{array}{l}\text { sample } \\
\text { no. }\end{array}$ & temperature $/{ }^{\circ} \mathrm{C}$ & $\begin{array}{l}\text { protective } \\
\text { reagent }\end{array}$ & $\begin{array}{l}\text { amount of } \\
\text { protective reagent }\end{array}$ & $\begin{array}{l}\text { recovery of } \\
\text { Cs/\% }\end{array}$ \\
\hline 1 & 350 & no & & $\begin{array}{l}31 \pm 8 \\
(n=3)\end{array}$ \\
\hline 2 & 400 & no & & $\begin{array}{l}32 \pm 8 \\
(n=3)\end{array}$ \\
\hline 3 & 450 & no & & $\begin{array}{l}34 \pm 9 \\
\quad(n=3)\end{array}$ \\
\hline 4 & 350 & $\mathrm{H}_{3} \mathrm{PO}_{4}$ & $1.5 \mathrm{mmol}$ & $\begin{array}{l}67 \pm 7 \\
(n=3)\end{array}$ \\
\hline 5 & 350 & $\mathrm{LiCl}$ & $8 \mathrm{mg}$ & $\begin{array}{c}47 \pm 6 \\
(n=3)\end{array}$ \\
\hline 6 & 350 & $\mathrm{LiCl}$ & $24 \mathrm{mg}$ & $\begin{array}{l}76 \pm 5 \\
(n=3)\end{array}$ \\
\hline 7 & 350 & $\mathrm{LiCl}$ & $40 \mathrm{mg}$ & $\begin{array}{l}91 \pm 3 \\
\quad(n=3)\end{array}$ \\
\hline 8 & 350 & $\mathrm{LiCl}$ & $60 \mathrm{mg}$ & $\begin{array}{l}99 \pm 3 \\
(n=3)\end{array}$ \\
\hline 9 & 350 & $\mathrm{LiCl}$ & $80 \mathrm{mg}$ & $\begin{aligned} 100 & \pm 3 \\
(n & =3)\end{aligned}$ \\
\hline 10 & 350 & $\mathrm{NaCl}$ & $80 \mathrm{mg}$ & $\begin{array}{l}91 \pm 5 \\
(n=3)\end{array}$ \\
\hline 11 & 350 & $\mathrm{CaCl}_{2}$ & $80 \mathrm{mg}$ & $\begin{array}{l}89 \pm 5 \\
(n=3)\end{array}$ \\
\hline
\end{tabular}

Cesium chloride is not a volatile species, with a melting point of $646{ }^{\circ} \mathrm{C}$ and a boiling point of $1297^{\circ} \mathrm{C}$. The loss of cesium in the heating process might be attributed to its small amount $(<20 \mu \mathrm{g})$ compared to the extremely large amount of $\mathrm{NH}_{4} \mathrm{Cl}$, resulting in a $\mathrm{NH}_{4} \mathrm{Cl} / \mathrm{CsCl}$ mass ratio of more than 5 $\times 10^{5}$. During the sublimation process, a massive amount of $\mathrm{NH}_{4} \mathrm{Cl}$ gas (possibly also with some $\mathrm{NH}_{3}$ and $\mathrm{HCl}$ ) was released, and a trace amount of $\mathrm{CsCl}$ wrapped in the $\mathrm{NH}_{4} \mathrm{Cl}$ might be carried out in this process. It was noticed that, by adding $\mathrm{H}_{3} \mathrm{PO}_{4}$ into the eluate before evaporation, the recovery of cesium was significantly improved to $67 \%$ (Table 1). Addition of other salts such as $\mathrm{LiCl}, \mathrm{NaCl}$, and $\mathrm{CaCl}_{2}$, the recovery of cesium was also significantly improved; almost quantitative recovery of $\mathrm{Cs}$ was obtained when more than 60 mg of $\mathrm{LiCl}$ was added. $\mathrm{LiCl}, \mathrm{NaCl}$, and $\mathrm{CaCl}_{2}$ are not volatile compounds; $\mathrm{CsCl}$ might be adsorbed on the particles of these salts during the sublimation of $\mathrm{NH}_{4} \mathrm{Cl}$, thus preventing the loss of $\mathrm{CsCl}$. The increased recoveries of Cs with the amount of $\mathrm{LiCl}$ of less than $60 \mathrm{mg}$ (Table 1) confirmed that the sufficient amount of particles/salt are important for preventing loss of Cs during sublimation of $\mathrm{NH}_{4} \mathrm{Cl}$. However, cations of $\mathrm{Li}^{+}, \mathrm{Na}^{+}$, and $\mathrm{Ca}^{2+}$ also compete with $\mathrm{Cs}^{+}$to adsorb on the cation exchange resin during the purification of cesium. Due to much low relative selectivity of $\mathrm{Li}(0.85)$ on the cation exchange resin (AG 50W) compared to $\mathrm{Cs}$ (2.7), $\mathrm{Na}$ (1.5), and Ca (3.9), $\mathrm{LiCl}$ has much less influence on the adsorption of $\mathrm{Cs}^{+}$ on the cation exchange resin. Therefore $60 \mathrm{mg}$ of $\mathrm{LiCl}$ was selected in this study.

Elimination of $\mathrm{Ba}$ and Other Interfering Elements Using Cation Exchange Chromatography. Although AMP-PAN is a specific resin for separation of Cs from the sample matrix, the removal efficiencies for most of interfering elements, such as $\mathrm{Ba}, \mathrm{Mo}, \mathrm{Sb}$ and $\mathrm{Sn}$, are not sufficient high for the low-level ${ }^{135} \mathrm{Cs}$ measurement by ICP-MS/MS. Besides the interfering elements, $\mathrm{Li}^{+}$added in the last step also needs to be removed due to matrix effect in ICP-MS/MS measurement. Based on the different affinity/relative selectivity of $\mathrm{Cs}^{+}$and these interfering elements, strong acidic cation exchange resin (AG 50W-X8) was applied for purification of cesium. The affinity of $\mathrm{Cs}^{+}$is much higher than that of $\mathrm{Li}^{+}$but lower than that of $\mathrm{Ba}^{2+} . \mathrm{Li}^{+}$is first removed from the column; $\mathrm{Cs}^{+}$is then eluted but keeping $\mathrm{Ba}^{2+}$ on the column. The decontamination factor of $\mathrm{Ba}$ relies on the eluent and its concentration. After removal of $\mathrm{NH}_{4} \mathrm{Cl}$ by sublimation, the cesium sample was prepared in a small volume of $1.5 \mathrm{M} \mathrm{NH}_{3} \cdot \mathrm{H}_{2} \mathrm{O}(10 \mathrm{~mL})$. In this alkaline media, $\mathrm{Mo}, \mathrm{Sn}$, and $\mathrm{Sb}$ can be converted to anion species $\left(\mathrm{MoO}_{4}{ }^{2-}, \mathrm{Sn}(\mathrm{OH})_{6}{ }^{2-}\right.$ and $\left.\mathrm{SbO}_{3}{ }^{-}\right)$, which are not adsorbed on the cation exchange resin. After loading the Cs sample solution to AG $50 \mathrm{~W}-\mathrm{X} 8$ column, and rinsing with 50 $\mathrm{mL}$ of $1.5 \mathrm{M} \mathrm{NH}_{3} \cdot \mathrm{H}_{2} \mathrm{O}$ and $20 \mathrm{~mL}$ of $\mathrm{H}_{2} \mathrm{O}$, anion species of $\mathrm{Mo}, \mathrm{Sn}$, and $\mathrm{Sb}$ can be well eliminated. $\mathrm{HNO}_{3}$ was then used for elution of Cs, which can avoid introduction of any salt to the final solution and benefit for sensitive measurement of cesium isotopes. Meanwhile, the eluate can be evaporated to dryness and prepared in a small volume solution for ICP-MS/ MS measurement.

The elution profiles (Figure 2) show that $2.0 \mathrm{M} \mathrm{HNO}_{3}$ can quickly elute $\mathrm{Cs}$ from the column, but $\mathrm{Ba}$ can be also quickly

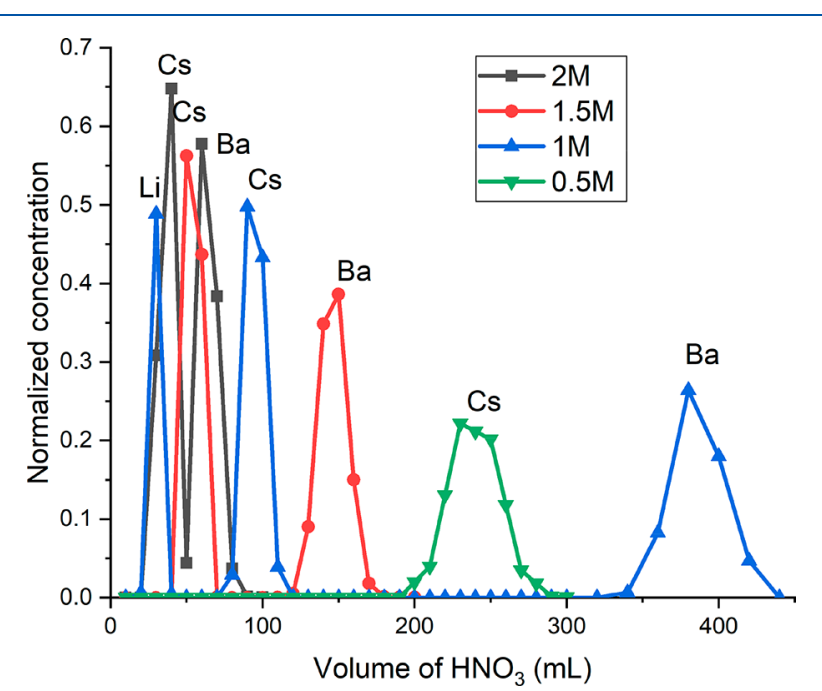

Figure 2. Elution profiles of $\mathrm{Cs}, \mathrm{Ba}$, and $\mathrm{Li}$ on $10 \mathrm{~mL}$ of AG50-X8 column $\left(\phi 1.0 \times 20 \mathrm{~cm}, \mathrm{H}^{+}\right.$form $)$with different concentrations of $\mathrm{HNO}_{3}$.

eluted and overlap with Cs eluate. By eluting with lower concentrations of $\mathrm{HNO}_{3}$ (e.g., $0.5 \mathrm{M}$ ), Cs can be completely separated from $\mathrm{Ba}$, but a large volume of eluent is needed. The optimal elution was achieved using $1 \mathrm{M} \mathrm{HNO}_{3}$, and in this case, $\mathrm{Cs}$ can be completely separated from $\mathrm{Ba}$ and $\mathrm{Li}$ with 70 $\mathrm{mL}$ of $1 \mathrm{M} \mathrm{HNO}_{3}$, meanwhile most of $\mathrm{K}^{+}$and $\mathrm{Rb}^{+}$can be also removed due to their lower affinity compared to $\mathrm{Cs}^{+} .{ }^{14} \mathrm{~A} 10$ $\mathrm{mL}$ cation exchange resin (AG50W-X8) in a column of $\phi 1.0 \times$ $20 \mathrm{~cm}$ was employed for obtaining a better separation of Cs from $\mathrm{Ba}, \mathrm{Rb}$, and $\mathrm{K}$.

The decontamination factors of $\mathrm{Ba}, \mathrm{Li}, \mathrm{Mo}, \mathrm{Sn}$, and $\mathrm{Sb}$ in the cation exchange chromatographic separation procedure were monitored by determination of the concentrations of these elements in the final eluted Cs fraction using ICP-MS and compared with the initiate amounts of these elements in the leached sample solution. The overall decontamination factors 
of $4 \times 10^{7}$ for Ba, $4 \times 10^{6}$ for Li, $4 \times 10^{5}$ for Mo, $3 \times 10^{5}$ for $\mathrm{Sn}$, and $2 \times 10^{5}$ for $\mathrm{Sb}$ were achieved, which are better or comparable compared to the reported values using combined chromatographic purification (AMP-PAN, AGMP-1 M, and AG 50W-X8). ${ }^{14,18}$ In consideration of all steps including ICPMS measurement, the entire analysis of a batch of 8 samples can be completed within 3 days. The overall chemical yields of ${ }^{135} \mathrm{Cs}$ were measured by counting the ${ }^{137} \mathrm{Cs}$ in the original samples and the final separated cesium solution by gamma spectrometry to be more than $85 \%$ for soils from Sweden and Ukraine. The recoveries of radiocesium in each step were also measured by counting ${ }^{137} \mathrm{Cs}$, being about $90 \%$ for acid leaching step, $97 \%$ for AMP-PAN column separation, 99\% for $\mathrm{NH}_{4} \mathrm{Cl}$ sublimation process, and $99 \%$ for cation exchange resin purification step. A slightly lower chemical yields of $60-70 \%$ for cesium was obtained for Danish soil samples, which is mainly attributed to the lower leaching rate of cesium in the step of aqua regia leaching of big soil samples $(60 \mathrm{~g})$. However, this can be improved by dividing big sample into a few aliquots for leaching to increase the leaching efficiency.

For the analysis of real environmental samples, the Cs eluate in $1.0 \mathrm{M} \mathrm{HNO}_{3}$ was evaporated to dryness and then prepared in $2.0 \mathrm{~mL}$ of $0.3 \mathrm{M} \mathrm{HNO}_{3}$ for ICP-MS/MS measurement. The concentrations of $\mathrm{Ba}, \mathrm{Mo}, \mathrm{Sb}$, and $\mathrm{Sn}$ in the final Cs fraction were less than $0.1,1,0.2$, and $0.2 \mathrm{ng} / \mathrm{mL}$ respectively.

Measurement of Low-Level ${ }^{135} \mathrm{Cs}$ and ${ }^{137} \mathrm{Cs}$ by ICPMS/MS. The major challenges in the measurement of ultralow level ${ }^{135} \mathrm{Cs}$ and ${ }^{137} \mathrm{Cs}(<2 \mathrm{fg} / \mathrm{g})$ in environmental samples are elimination of isobaric interference of stable ${ }^{135} \mathrm{Ba}$ and ${ }^{137} \mathrm{Ba}$, interference of polyatomic ions including ${ }^{95} \mathrm{Mo}^{40} \mathrm{Ar}^{+}$, ${ }^{97} \mathrm{Mo}^{40} \mathrm{Ar}^{+},{ }^{119} \mathrm{Sn}^{16} \mathrm{O}^{+}$, and ${ }^{121} \mathrm{Sb}^{16} \mathrm{O}^{+}$and suppressing the tailing of stable ${ }^{133} \mathrm{Cs}$. In this work, two sequential quadrupole mass filters equipped in the Agilent 8800 was used to reduce the tailing influence of ${ }^{133} \mathrm{Cs}$; collision reaction technique with $\mathrm{N}_{2} \mathrm{O}$ as reaction/collision gas was used to eliminate $\mathrm{Ba}$ interference, as well as polyatomic ions interference. The results (Figure 3) show that the signal intensities of $\mathrm{Ba}^{+}$ions were significantly decreased by 5 orders of magnitude when the flow rates of $\mathrm{N}_{2} \mathrm{O}$ gas injected to the DRC were increased from 0 to $0.9 \mathrm{~mL} / \mathrm{min}$., while the signal intensities of $\mathrm{Cs}^{+}$ions were only slightly reduced with the increased flow rates of $\mathrm{N}_{2} \mathrm{O}$.

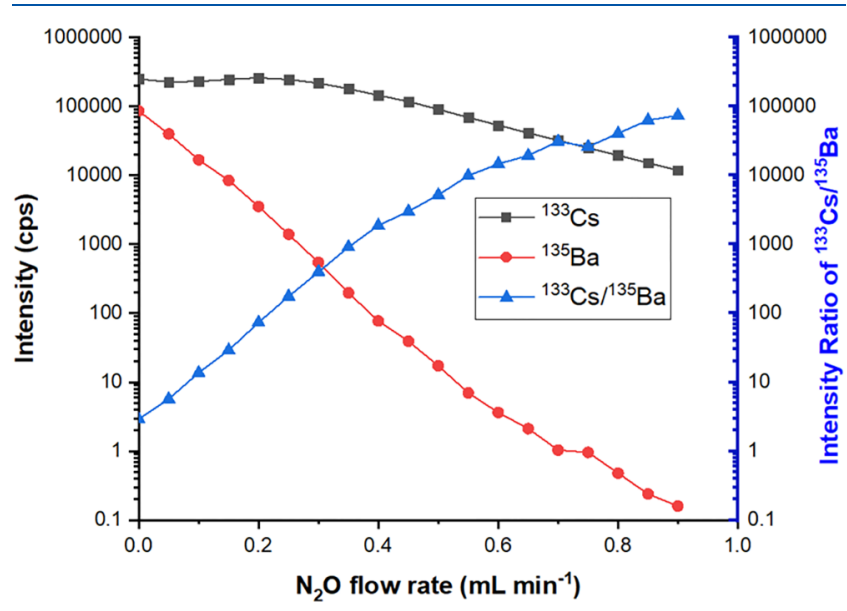

Figure 3. Variation of intensities of $\mathrm{Cs}^{+}$and $\mathrm{Ba}^{+}$signal and ratios of ${ }^{133} \mathrm{Cs} /{ }^{135} \mathrm{Ba}$ with the flow rates of $\mathrm{N}_{2} \mathrm{O}$ injected to the DRC. The standard solutions of $\mathrm{Cs}(1.0 \mathrm{ng} / \mathrm{mL})$ and $\mathrm{Ba}(5.0 \mathrm{ng} / \mathrm{mL})$ were used in this experiment.
This is attributed to the high affinity of $\mathrm{Ba}^{+}$ion with oxygen atom (92.8) compared to $\mathrm{Cs}^{+}$ion (14) in $\mathrm{N}_{2} \mathrm{O}$ gas, ${ }^{28}$ causing formation of $\mathrm{BaO}^{+}$but not $\mathrm{CsO}^{+}$. With $0.70 \mathrm{~mL} / \mathrm{min}$ of $\mathrm{N}_{2} \mathrm{O}$ as reaction gas, the measured ${ }^{133} \mathrm{Cs} /{ }^{135} \mathrm{Ba}$ ratios were improved by a factor of more than $2 \times 10^{4}$, while the sensitivity of Cs was decreased by a factor of 8 . At this condition, the measured sensitivity of Cs is $3.4 \times 10^{5} \mathrm{cps} / \mathrm{ppb}$ with the Apex-Q system, while the contributions of $0.2 \mathrm{ng} / \mathrm{mL} \mathrm{Ba}$ at the $m / z=135$ and 137 were less than $0.3 \mathrm{cps}$.

The interferences from polyatomic ions on $\mathrm{m} / z=135$ and 137, such as ${ }^{95} \mathrm{Mo}^{40} \mathrm{Ar}^{+},{ }^{119} \mathrm{Sn}^{16} \mathrm{O}^{+},{ }^{97} \mathrm{Mo}^{40} \mathrm{Ar}^{+}$, and ${ }^{121} \mathrm{Sb}^{16} \mathrm{O}^{+}$ were investigated by measuring the signal intensities at $\mathrm{m} / z=$ 135 and 137 for different concentrations of single element standard solutions of $\mathrm{Mo}, \mathrm{Sn}$, and $\mathrm{Sb}$ at the optimal condition of ICP-MS/MS with $0.7 \mathrm{~mL} / \mathrm{min} . \mathrm{N}_{2} \mathrm{O}$ as reaction gas. The results (Figure S3) show that the signal intensities at $\mathrm{m} / \mathrm{z}=$ 135 and 137 were very low but increased with the concentrations of these elements in the standard solution, indicating the polyatomic ions formed by these elements were effectively destroyed in the DRC by the injected reaction/ collision gas. For $50 \mathrm{ng} / \mathrm{mL}$ solution of $\mathrm{Sn}, \mathrm{Sb}$, and $\mathrm{Mo}$, the measured intensities at $m / z$ of 135 and 137 were $4 \mathrm{cps}$ for $\mathrm{Sn}$, $70 \mathrm{cps}$ for $\mathrm{Sb}$, and $1 \mathrm{cps}$ for Mo. Although the concentration of Mo in the final Cs eluate was relatively higher $(1 \mathrm{ng} / \mathrm{mL})$ compared to other elements, the interference from Mo $(<0.02$ cps) is still negligible. Because the concentrations of $\mathrm{Sn}$ and $\mathrm{Sb}$ in the final purified sample solution were less than $0.2 \mathrm{ng} / \mathrm{mL}$, the interferences from these elements on the measurement of ${ }^{135} \mathrm{Cs}$ and ${ }^{137} \mathrm{Cs}(<0.3 \mathrm{cps})$ are also negligible. Meanwhile, it also indicates that the effective removal of these elements from Cs fraction is critical for accurate measurement of the low-level ${ }^{135} \mathrm{Cs}$ due to their relatively high concentrations in the soil and sediment samples (about $1-3 \mu \mathrm{g} / \mathrm{g} \mathrm{Mo}, \mathrm{Sb}$ and $\mathrm{Sn}$ ) compared to ${ }^{135} \mathrm{Cs}\left(<3 \times 10^{-15} \mathrm{~g} / \mathrm{g}\right)$.

The abundance sensitivity is another critical interference for the measurement of low-level ${ }^{135} \mathrm{Cs}$ due to the relatively high stable cesium concentration in environmental samples (1-3 $\mu \mathrm{g} / \mathrm{g})$ and low atomic ratio of ${ }^{135} \mathrm{Cs} /{ }^{133} \mathrm{Cs}\left(<10^{-8}\right.$ in background area); application of two sequential quadrupole mass filters for the measurement of ${ }^{135} \mathrm{Cs}$ by setting $\mathrm{m} / z=135$ for both quadrupoles significantly improved the abundance sensitivity. The signal intensity at $\mathrm{m} / z=135$ was measured using a cesium standard solution of $50 \mu \mathrm{g} / \mathrm{mL}$ to evaluate the tailing influence of ${ }^{133} \mathrm{Cs}$; the abundance sensitivity (ratio of the count rate at $m / z=135$ to that at $m / z=133$ ) was estimated to be less than $1 \times 10^{-11}$. This is about 3 orders of magnitude lower than the ${ }^{135} \mathrm{Cs} /{ }^{133} \mathrm{Cs}$ ratio in normal environmental samples, therefore sufficient good for reliable measurement of ultralow level ${ }^{135} \mathrm{Cs}$ without a correction for the tailing contribution of ${ }^{133} \mathrm{Cs}$. However, if large amount of stable cesium (e.g., $>2 \mathrm{mg}$ ) was used as carrier in the chemical separation, the interference of ${ }^{133} \mathrm{Cs}$ tailing will be too serious (corresponding to $20 \mathrm{fg}$ of ${ }^{135} \mathrm{Cs}$ ) to obtain an accurate result of low-level ${ }^{135} \mathrm{Cs}$ even for a correction. Therefore, no stable cesium could be added as carrier in the chemical separation of cesium for the determination of ${ }^{135} \mathrm{Cs}$ using ICP-MS/MS.

Detection Limit of the Method for ${ }^{135} \mathrm{Cs}$. By using Apex-Q sample introduction system, the measurement sensitivity was significantly improved to $3.4 \times 10^{5} \mathrm{cps}$ for 1 $\mathrm{ng} / \mathrm{mL}{ }^{133} \mathrm{Cs}$ standard solution. The count rates at $\mathrm{m} / \mathrm{z}$ of 135 and 137 in the procedure blanks were measured to be $0.3 \pm$ 0.2 cps. Based on these performances, minimum detectable amount of ${ }^{135} \mathrm{Cs}$ and ${ }^{137} \mathrm{Cs}$ can be estimated to be $1.8 \times 10^{-15}$ 
Table 2. Comparison of the Measured ${ }^{135} \mathrm{Cs}$ Concentrations and ${ }^{135} \mathrm{Cs} /{ }^{137} \mathrm{Cs}$ Atomic Ratios in Standard Reference Materials with the Reported Values

\begin{tabular}{|c|c|c|c|c|}
\hline sample & matrix & ${ }^{135} \mathrm{Cs} /{ }^{137} \mathrm{Cs}$ atomic ratio (this work) & ${ }^{135} \mathrm{Cs}$ activity $(\mathrm{mBq} / \mathrm{kg})$ & ${ }^{135} \mathrm{Cs} /{ }^{137} \mathrm{Cs}$ atomic ratios (in literature) \\
\hline IAEA- $375^{a}$ & soil & $0.30 \pm 0.02(n=3)$ & $24.3 \pm 1.6$ & $\begin{array}{l}0.30 \pm 0.01^{29} \\
0.30 \pm 0.01^{11} \\
0.31 \pm 0.01^{12} \\
0.27 \pm 0.02^{30} \\
0.32 \pm 0.01^{31}\end{array}$ \\
\hline IAEA-330 ${ }^{a}$ & spinach & $0.29 \pm 0.02(n=1)$ & $8.12 \pm 0.56$ & $0.29 \pm 0.02^{9}$ \\
\hline IAEA- $385^{b}$ & sediment & $1.10 \pm 0.17(n=3)$ & $0.30 \pm 0.05$ & $\begin{array}{l}0.80 \pm 0.16^{12} \\
1.21 \pm 0.14^{14}\end{array}$ \\
\hline
\end{tabular}

${ }^{a}$ Decay corrected to April $1986 .{ }^{b}$ Decay corrected to Jan 2015. The results for soil and sediment are the average and 1SD of 3 replicate samples, for spinach are the measurement results with overall analytical uncertainties $(k=1)$.

$\mathrm{g} / \mathrm{mL}$ using 3 times standard deviation of the procedure blanks. For $60 \mathrm{~g}$ of soil sample, the detection limit of the method for ${ }^{135} \mathrm{Cs}$ and ${ }^{137} \mathrm{Cs}$ can be calculated to be $9.1 \times 10^{-17}$ $\mathrm{g} / \mathrm{g}$ (or $0.30 \mathrm{mBq} / \mathrm{g}$ for ${ }^{137} \mathrm{Cs}$ and $3.9 \mathrm{nBq} / \mathrm{g}$ for ${ }^{135} \mathrm{Cs}$ ) considering a recovery of $65 \%$ for cesium and $2 \mathrm{~mL}$ final solution prepared for measurement; this value is more than 1 order of magnitude better than the reported value using ICPMS/MS. ${ }^{14}$

Validation of the Developed Method. There is no standard reference material of similar matrix as soil and sediment with certified for ${ }^{135} \mathrm{Cs}$ concentration or ${ }^{135} \mathrm{Cs} /{ }^{137} \mathrm{Cs}$ ratio available, the standard reference materials of soil (IAEA375 , collected from contaminated area by Chernobyl accident in Russia), sediment (IAEA-385, collected from the Irish Sea) and spinach (IAEA-330, collected from Polesskoe, Kiev, Ukraine) with the reported ${ }^{135} \mathrm{Cs} /{ }^{137} \mathrm{Cs}$ ratios in literatures were therefore analyzed using the developed method. The results (Table 2) show that the measured ${ }^{135} \mathrm{Cs} /{ }^{137} \mathrm{Cs}$ atomic ratios for IAEA-375 and IAEA-330 are in well agreement with the reported data in the literature, indicating the developed method is reliable and accurate for the determination of ${ }^{135} \mathrm{Cs}$ and ${ }^{135} \mathrm{Cs} /{ }^{137} \mathrm{Cs}$ ratio in environmental samples. As for IAEA385 sediment, only two data were reported, ${ }^{12,14}$ and our result agreed with the value reported by Zheng. ${ }^{14}$

${ }^{135} \mathrm{Cs} /{ }^{137} \mathrm{Cs}$ Ratios in Soil from Denmark, Sweden, and Ukraine. Soil samples collected from Denmark, Sweden, and Ukraine were analyzed for ${ }^{135} \mathrm{Cs}$ concentrations and ${ }^{135} \mathrm{Cs} /{ }^{137} \mathrm{Cs}$ atomic ratios using the developed method. The results (Table 3) show that the measured ${ }^{135} \mathrm{Cs} /{ }^{137} \mathrm{Cs}$ atomic ratios in the soils collected from Gavle, Sweden and Feofaniya, Ukraine are similar (0.65-0.71), although the ${ }^{137} \mathrm{Cs}$ concentrations $(140-1650 \mathrm{~Bq} / \mathrm{kg})$ are different in these samples by a factor of $2-10$. While a much higher ${ }^{135} \mathrm{Cs} /{ }^{137} \mathrm{Cs}$ atomic ratios of $(2.08-2.68)$, but a much lower ${ }^{137} \mathrm{Cs}$ concentrations $(3-8$ $\mathrm{Bq} / \mathrm{kg}$ ) were observed in soil samples from Denmark. This should be attributed to the different sources of ${ }^{135} \mathrm{Cs}$ and ${ }^{137} \mathrm{Cs}$ in these soil samples. As high as $1650 \mathrm{~Bq} / \mathrm{kg}$ of ${ }^{137} \mathrm{Cs}$ was measured in the soil collected from Gavle, Sweden and 142$286 \mathrm{~Bq} / \mathrm{kg}$ in Feofaniya, Ukraine, they are 1-3 orders of magnitude higher than the level in the soil received only global fallout. ${ }^{32}$ The measured ${ }^{135} \mathrm{Cs} /{ }^{137} \mathrm{Cs}$ ratios $(0.65-0.71)$ (corresponding to $0.30-0.32$ with decay correction to April 1986) are similar to those reported ratios in the Chernobyl accident derived radiocesium $(0.28-0.32),{ }^{9}$ indicating that most of radiocesium in these samples were originated from the Chernobyl accident fallout. It has been also reported that Gavle in Sweden and Feofaniya in Ukraine had received heavily radioactive fallout from Chernobyl accident in 1986,
Table 3. Analytical Results of ${ }^{135} \mathrm{Cs}$ Concentrations and ${ }^{135} \mathrm{Cs} /{ }^{137} \mathrm{Cs}$ Ratios in Surface Soil Samples from Denmark, Sweden, and Ukraine ${ }^{a}$

$\begin{array}{cccc}\text { sample } & \begin{array}{c}{ }^{137} \mathrm{Cs} \text { activity } \\ (\mathrm{Bq} / \mathrm{kg})\end{array} & \begin{array}{c}{ }^{135} \mathrm{Cs} /{ }^{137} \mathrm{Cs} \\ \text { atomic ratios }\end{array} & \begin{array}{c}{ }^{135} \mathrm{Cs} \text { activity } \\ (\mathrm{mBq} / \mathrm{kg})\end{array} \\ \begin{array}{c}\text { Danish soil-1 } \\ (n=2)\end{array} & 3.32 \pm 0.16 & 2.68 \pm 0.53 & 0.12 \pm 0.02 \\ \begin{array}{c}\text { Danish soil-2 } \\ (n=2)\end{array} & 8.03 \pm 0.31 & 2.08 \pm 0.31 & 0.23 \pm 0.03 \\ \begin{array}{c}\text { Sweden soil } \\ (n=1)\end{array} & 1650 \pm 18 & 0.66 \pm 0.06 & 14.7 \pm 1.03 \\ \begin{array}{c}\text { Ukraine soil-1 } \\ (n=1)\end{array} & 283 \pm 3 & 0.65 \pm 0.07 & 2.49 \pm 0.27 \\ \begin{array}{c}\text { Ukraine soil-2 } \\ (n=1)\end{array} & 142 \pm 3 & 0.71 \pm 0.08 & 1.36 \pm 0.15 \\ \begin{array}{c}\text { Ukraine soil-3 } \\ (n=1)\end{array} & 150 \pm 3 & 0.71 \pm 0.08 & 1.44 \pm 0.16 \\ & & & \end{array}$

${ }^{a}$ All ${ }^{137} \mathrm{Cs}$ data are decay corrected to 1 st Feb 2020. The uncertainties presented here are the overall uncertainty with $k=1$

and other anthropogenic radionuclides related to Chernobyl accident were observed in these samples. ${ }^{33} \mathrm{~A}$ much lower ${ }^{137} \mathrm{Cs}$ concentrations were observed in the Danish soil samples. The measured ${ }^{135} \mathrm{Cs} /{ }^{137} \mathrm{Cs}$ ratios in two Danish soil samples are $2.68 \pm 0.53$ (Soil-1) and $2.08 \pm 0.31$ (Soil-2), which is about 3-4 times higher than the ratios measured in the Chernobyl accident contaminated soil from Gavle, Sweden and Feofaniya, Ukraine. Danish Soil-1 was collected from upper $0-5 \mathrm{~cm}$ in Roskilde in 2019, while the Danish Soil-2 is a mixture of soil samples collected from 0 to $5 \mathrm{~cm}$ depth at 8 different sites over Denmark in 1987 (Table S2). Based on the assumption of only two sources of ${ }^{137} \mathrm{Cs}$ and ${ }^{135} \mathrm{Cs}$ in Denmark (global fallout and Chernobyl accident fallout) and the reported ${ }^{135} \mathrm{Cs} /{ }^{137} \mathrm{Cs}$ atomic ratios of $3.7 \pm 0.4$ for the global fallout and $0.65 \pm 0.04$ for Chernobyl accident releases (decay corrected to Feb 2020), ${ }^{9,11}$ the contributions of radiocesium from Chernobyl accident can be estimated to be $31 \%$ for Soil- 1 and $51 \%$ for Soil-2. The estimated value in Soil-2 agree well with the estimation through the monitoring of ${ }^{137} \mathrm{Cs}$ level in soil at 8 different sites in Denmark collected before Chernobyl accident (1983) and after the Chernobyl accident (1987; Table S2). A less contribution of Chernobyl accident was estimated in Soil-1 compared to the Soil-2. The ${ }^{137} \mathrm{Cs}$ concentration $(3.3 \mathrm{~Bq} / \mathrm{kg})$ in the Soil-1 is also lower than that in Soil-2 $(8.0 \mathrm{~Bq} / \mathrm{kg})$ by a factor of 2.4, which supports the less fallout of Chernobyl accident in this site. This is the lowest radiocesium level environmental sample ever used for the radiocesium ratios determination by ICP-MS/MS, which will broaden the 
application of ${ }^{135} \mathrm{Cs} /{ }^{137} \mathrm{Cs}$ as a tracer in environmental process studies.

The analytical results of these soil samples demonstrate that the developed method could be successfully applied for the determination of ${ }^{135} \mathrm{Cs}$ concentrations and ${ }^{135} \mathrm{Cs} /{ }^{137} \mathrm{Cs}$ ratios in ordinary environmental samples (with ${ }^{137} \mathrm{Cs}$ concentration down to $3.3 \mathrm{~Bq} / \mathrm{kg}$ ). It also indicates that the ${ }^{135} \mathrm{Cs} /{ }^{137} \mathrm{Cs}$ ratios can be used as a unique fingerprint for discriminating the sources of radioactive contamination and estimating their contributions to the total inventory, which will be useful for nuclear forensics and environmental tracer studies.

\section{CONCLUSION}

A method was developed for the determination of ${ }^{135} \mathrm{Cs}$ concentrations and ${ }^{135} \mathrm{Cs} /{ }^{137} \mathrm{Cs}$ atomic ratios in environmental solid samples by coupling AMP-PAN and AG 50W-X8 chromatographic separation with ICP-MS/MS measurement. A selective elution of $\mathrm{Cs}$ using $\mathrm{NH}_{4} \mathrm{Cl}$ from AMP-PAN without dissolution of the AMP component was proposed for the first time, thereby significantly reducing the burden for removal of a large amount of molybdenum from cesium solution. Ammonium chloride in the eluate of Cs was removed satisfactorily by sublimation at $350{ }^{\circ} \mathrm{C}$ with the addition of $\mathrm{LiCl}$ to prevent cesium loss during sublimation. In combination with cation exchange chromatographic separation, high decontamination factors for $\mathrm{Ba}, \mathrm{Mo}, \mathrm{Sb}$, and Sn were achieved, thus eliminating the interference of these elements on the measurements of ${ }^{135} \mathrm{Cs}$ and ${ }^{137} \mathrm{Cs}$ by ICP-MS/MS. A detection limit of $9.1 \times 10^{-17} \mathrm{~g} / \mathrm{g}$ for ${ }^{135} \mathrm{Cs}$ and ${ }^{137} \mathrm{Cs}$ was achieved for $60 \mathrm{~g}$ of soil sample. The analytical method has been validated by analysis of reference materials IAEA-375, IAEA-330, and IAEA-385 and successfully applied to determine ${ }^{135} \mathrm{Cs} /{ }^{137} \mathrm{Cs}$ in environmental soil samples from Denmark, Sweden and Ukraine. The ${ }^{135} \mathrm{Cs} /{ }^{137} \mathrm{Cs}$ atomic ratios in Danish soil (2.08-2.68) are much higher than that in the Swedish and Ukrainian soil (0.65-0.71), suggesting their different sources. About 50\% Chernobyl derived radiocesium in the Danish soil was estimated. This demonstrated that the developed method for determination of ${ }^{135} \mathrm{Cs} /{ }^{137} \mathrm{Cs}$ can be used to identify the sources of radioactive contamination and estimate their contribution to the total inventory, and a broad application of ${ }^{135} \mathrm{Cs} /{ }^{137} \mathrm{Cs}$ as a tracer in nuclear forensics and environmental studies can be foreseen.

\section{ASSOCIATED CONTENT}

\section{SI Supporting Information}

The Supporting Information is available free of charge at https://pubs.acs.org/doi/10.1021/acs.analchem.0c01153.

Three figures and two tables of additional expermental details (PDF)

\section{AUTHOR INFORMATION}

\section{Corresponding Author}

Xiaolin Hou - Department of Environmental Engineering,

Technical University of Denmark, Roskilde DK-4000,

Denmark; ๑ orcid.org/0000-0002-4851-4858; Phone: +4521325129; Email: xiho@dtu.dk

\section{Authors}

Liuchao Zhu - Department of Environmental Engineering, Technical University of Denmark, Roskilde DK-4000, Denmark
Jixin Qiao - Department of Environmental Engineering, Technical University of Denmark, Roskilde DK-4000,

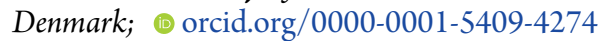

Complete contact information is available at: https://pubs.acs.org/10.1021/acs.analchem.0c01153

\section{Author Contributions}

The manuscript was written through contributions of all authors. L.Zhu designed and implemented the experiment and drafted the manuscript, X.Hou designed research plan and supervised the experiment, and X.Hou and J.Qiao revised the manuscript. All authors have given approval to the final version of the manuscript.

\section{Notes}

The authors declare no competing financial interest.

\section{REFERENCES}

(1) Russell, B. C.; Croudace, I. W.; Warwick, P. E. Anal. Chim. Acta 2015, 890, 7-20.

(2) Masson, O.; Bieringer, J.; Brattich, E.; Dalheimer, A.; Estier, S.; Penev, I.; Ringer, W.; Schlosser, C.; Steinkopff, T.; Steinmann, P.; Tositti, L.; Van Beek, P.; Vismes-Ott, A. d. J. Environ. Radioact. 2016, 162-163, 14-22.

(3) Rostan, J. C.; Juget, J.; Brun, A. M. Sci. Total Environ. 1997, 193, 251-262.

(4) Kershaw, P.; Baxter, A. Deep Sea Res., Part II 1995, 42, 14131448.

(5) Bailly du Bois, P.; Laguionie, P.; Boust, D.; Korsakissok, I.; Didier, D.; Fievet, B. J. Environ. Radioact. 2012, 114, 2-9.

(6) Chao, J.; Tseng, C. Nucl. Instrum. Methods Phys. Res., Sect. A 1996, 372, 275-279.

(7) Delmore, J. E.; Snyder, D. C.; Tranter, T.; Mann, N. R. J. Environ. Radioact. 2011, 102, 1008-1011.

(8) Lee, T.; Teh-Lung, K.; Hsiao-Ling, L.; Ju-Chin, C. Geochim. Cosmochim. Acta 1993, 57, 3493-3497.

(9) Snow, M. S.; Snyder, D. C. J. Environ. Radioact. 2016, 151, 258263.

(10) Zheng, J.; Tagami, K.; Bu, W.; Uchida, S.; Watanabe, Y.; Kubota, Y.; Fuma, S.; Ihara, S. Environ. Sci. Technol. 2014, 48, 54335438.

(11) Taylor, V. F.; Evans, R. D.; Cornett, R. J. J. Environ. Radioact. 2008, 99, 109-118.

(12) Yang, G.; Tazoe, H.; Yamada, M. Anal. Chim. Acta 2016, 908, 177-184.

(13) Zheng, J.; Bu, W.; Tagami, K.; Shikamori, Y.; Nakano, K.; Uchida, S.; Ishii, N. Anal. Chem. 2014, 86, 7103-7110.

(14) Zheng, J.; Cao, L.; Tagami, K.; Uchida, S. Anal. Chem. 2016 $88,8772-8779$.

(15) Snow, M. S.; Snyder, D. C.; Delmore, J. E. Rapid Commun. Mass Spectrom. 2016, 30, 523-532.

(16) Snow, M. S.; Snyder, D. C.; Clark, S. B.; Kelley, M.; Delmore, J. E. Environ. Sci. Technol. 2015, 49, 2741-2748.

(17) Karam, L. R.; Pibida, L.; McMahon, C. A. Appl. Radiat. Isot. 2002, 56, 369-374.

(18) Bu, W.; Tang, L.; Liu, X.; Wang, Z.; Fukuda, M.; Zheng, J.; Aono, T.; Hu, S.; Wang, X. J. Anal. At. Spectrom. 2019, 34, 301-309.

(19) Shibahara, Y.; Kubota, T.; Fujii, T.; Fukutani, S.; Ohta, T.; Takamiya, K.; Okumura, R.; Mizuno, S.; Yamana, H. J. Nucl. Sci. Technol. 2014, 51, 575-579.

(20) Dunne, J. A.; Richards, D. A.; Chen, H. W. Talanta 2017, 174, 347-356.

(21) Russell, B. C.; Warwick, P. E.; Croudace, I. W. Anal. Chem. 2014, 86, 11890-11896.

(22) Russell, B. C.; Croudace, I. W.; Warwick, P. E.; Milton, J. A. Anal. Chem. 2014, 86, 8719-8726.

(23) Song, M.; Probst, T.; Berryman, N. Fresenius' J. Anal. Chem. 2001, 370, 744-751. 
(24) McKinley, J. P.; Zeissler, C. J.; Zachara, J. M.; Serne, R. J.; Lindstrom, R. M.; Schaef, H. T.; Orr, R. D. Environ. Sci. Technol. 2001, 35, 3433-3441.

(25) Livens, F. R.; Howe, M. T.; Hemingway, J. D.; Goulding, K. W. T.; Howard, B. J. Eur. J. Soil Sci. 1996, 47, 105-112.

(26) Yamaguchi, A.; Tanaka, M.; Kurihara, Y.; Takahashi, Y. J. Radioanal. Nucl. Chem. 2018, 317, 545-551.

(27) Qiao, J.; Hansen, V.; Hou, X.; Aldahan, A.; Possnert, G. Appl. Radiat. Isot. 2012, 70, 1698-1708.

(28) Lavrov, V. V.; Blagojevic, V.; Koyanagi, G. K.; Orlova, G.; Bohme, D. K. J. Phys. Chem. A 2004, 108, 5610-5624.

(29) Snow, M. S.; Snyder, D. C.; Mann, N. R.; White, B. M. Int. J. Mass Spectrom. 2015, 381-382, 17-24.

(30) Nagy, P.; Vajda, N.; Sziklai-Laszlo, I.; Kovacs-Szeles, E.; Simonits, A. J. Radioanal. Nucl. Chem. 2014, 300, 615-627.

(31) Cao, L.; Zheng, J.; Tsukada, H.; Pan, S.; Wang, Z.; Tagami, K.; Uchida, S. Talanta 2016, 159, 55-63.

(32) Schuller, P.; Voigt, G.; Handl, J.; Ellies, A.; Oliva, L. J. Environ. Radioact. 2002, 62, 181-193.

(33) Hou, X.; Fogh, C. L.; Kucera, J.; Andersson, K. G.; Dahlgaard, H.; Nielsen, S. P. Sci. Total Environ. 2003, 308, 97-109. 